\title{
CHLORAMPHENICOL APPLIED IN CALCIUM ALGINATE CAPS FOR THE CONTROL OF EXPERIMENTAL CORNEAL INFECTION WITH PS. PYOCYANEA*
}

\author{
BY \\ M. KLEIN AND E. G. MILLWOOD
}

London

THE ophthalmic usefulness of an antibiotic is judged by the following criteria (Leopold, 1951):

(i) ease of penetration into the ocular tissues,

(ii) toxicity for ocular tissues,

(iii) effectiveness against standard experimental ocular infections,

(iv) effectiveness against clinical ocular infections.

The penetration of chloramphenicol was investigated by Leopold, Nichols, and Vogel (1950), who found that by using it as eyedrops in aqueous solution or in propylene glycol, or as an eye ointment, or as subconjunctival injections, the amount penetrating into the aqueous was between 5-22 micrograms. Langham (1951) made the important observation that chloramphenicol given systemically penetrates the blood-aqueous barrier with ease because it is fat-soluble and passes directly through the cells, and that the concentration in the aqueous may approach unity. Streptomycin on the other hand, being fat-insoluble, penetrates the permeable membranes with difficulty owing to the large size of its molecules, and the passage from the plasma into the aqueous is very poor. That chloramphenicol travels about twenty times faster through the blood-aqueous barrier than penicillin, is borne out by clinical experience that the use of systemic chloramphenicol in intra-ocular infections is very effective.

The toxicity was investigated by Azzolini and Faldi (1950), who found that a 0.25 per cent. solution was well tolerated in the rabbit's eye when given subconjunctivally, and that $0.3 \mathrm{ml}$. of a 0.25 per cent. solution was well tolerated in the anterior chamber. Injected into the vitreous, however, it brought about disorganization of the stroma.

Chloramphenicol is usually applied locally in eyedrops, but the poor solubility ( 0.25 per cent. in water, 0.5 per cent. in borate buffer solution) is to be noted. It is also given in ointment form and has been tried by different authorities in a variety of conditions, often with contradictory results. It is effective against many organisms not sensitive to penicillin or sulphonamides.

- Received for publication July $21,1952$. 


\section{Present Investigations}

The use of locally applied chloramphenicol as a prophylactic against experimental corneal infection with Ps. pyocyanea has been investigated. Since the concentration of the drug is low when applied by eyedrops or ointments (Leopold and others, 1950), and subconjunctival injections are not well tolerated (Sorsby, 1951), we have tried the effect of applying chloramphenicol powder by means of a flexible calcium alginate cap.

Preparation of Alginate Caps.-A metal mould* was dipped into a 2 to 4 per cent. solution of sodium alginate, so that the viscous fluid covered the corneal and scleral parts over an area the size of a contact lens. This was then dipped into a fluid made up of a concentrated solution of calcium chloride $0.1 \mathrm{ml}$, distilled water $25 \mathrm{ml}$., and 10 per cent. acetic acid $0.5 \mathrm{ml}$. After a few minutes under the influence of calcium ions, a transparent flexible cap was formed which retained its shape on being carefully removed from the mould. These calcium alginate were kept in a weak solution of calcium gluconate until required. Immediately before use the cap was trimmed to the approximate size of a rabbit's eye. After application to the eye, the cap was held in place by suturing the lids by means of a single suture in the middle.

Procedure.-Corneal ulcers were produced by intracorneal injection of a freshly subcultured 24-hr-old human pathogenic strain of Ps. pyocyanea. A tuberculin syringe and intradermal needle were used, and with the needle in the right layer a small wheal of 3-4 mm. diameter was produced on the cornea. If left untreated the corneal ulcer took a destructive course, ending in extensive corneal scarring or shrinkage of the globe.

Results.-The Table shows that of six treated rabbit eyes, three were clear after $24 \mathrm{hrs}$; and that the infection was light in two and moderately heavy in the last. One of the clear eyes subsequently became infected, but the other two remained clear. In the eyes which showed slight or moderate infection, progressive deterioration occurred. Thus a single dose of chloramphenicol was an effective prophylactic in two out of six eyes; in a further two eyes the infection was suppressed to some extent, but subsequently became worse; and in two eyes the drug afforded no protection at all.

These results were obtained by a single application of $60 \mathrm{mg}$. chloramphenicol powder. No subsequent treatment was given as the aim was to assess the protective effect of a single dose. However, it is reasonable to assume that in two more cases the infection would have been halted by repeated treatment.

When the lid sutures were removed on the second day the alginate caps were found in situ. Bacteriological examination of the cap from an eye in which the infection was controlled gave a negative result regarding $P s$. pyocyanea; in caps from eyes in which infection was not controlled Ps. pyocyanea was present.

Subconjunctival Injection.-In two further experiments (Nos 7 and 8), the subconjunctival injection of $30 \mathrm{mg}$. chloramphenicol suspended in sodium alginate solution gave no protection at all, and marked irritation occurred.

* Supplied by Messrs. G. Nissel and Co. 
TABLE

\begin{tabular}{|c|c|c|c|c|}
\hline $\begin{array}{l}\text { Eye } \\
\text { No. }\end{array}$ & Infection & Treatment & $\begin{array}{l}\text { Result after } \\
24 \mathrm{hrs}\end{array}$ & Remarks \\
\hline 1 & $\begin{array}{c}\text { Intracorneal } \\
\text { Ps. pyocyanea }\end{array}$ & \multirow{6}{*}{$\begin{array}{l}60 \mathrm{mg} \text {. chloramphenicol } \\
\text { in alginate cap }\end{array}$} & Clear & Remained clear \\
\hline 2 & $"$ & & Infection & $\begin{array}{l}\text { Progressively worse after } \\
\text { second day }\end{array}$ \\
\hline 3 & " & & Clear & Became infected later \\
\hline 4 & " & & Clear & Remained clear \\
\hline 5 & , & & Very light infection & Heavy infection later \\
\hline 6 & , & & Heavy infection & \\
\hline 7 & , & \multirow{2}{*}{$\begin{array}{l}30 \mathrm{mg} \text {. chloramphenicol } \\
\text { in alginate subcon- } \\
\text { junctival injection }\end{array}$} & \multirow{2}{*}{ Heavy infection } & \\
\hline 8 & , & & & \\
\hline 9 & $"$ & \multirow{2}{*}{ No treatment } & \multirow{2}{*}{ Heavy infection } & \\
\hline 10 & $"$ & & & \\
\hline 11 & $"$ & \multirow{2}{*}{ Empty alginate cap } & \multirow{2}{*}{ Heavy infection } & \\
\hline 12 & $"$ & & & \\
\hline 13 & None & \multirow{2}{*}{$\begin{array}{l}\text { Control to observe } \\
\text { effect of applying } \\
\text { empty alginate cap }\end{array}$} & \multirow{2}{*}{$\int \underset{\text { haze }}{\text { Slight }}$ corneal } & \multirow{2}{*}{ Cleared up in a few days } \\
\hline 14 & None & & & \\
\hline
\end{tabular}

Controls.-In two eyes which were injected with Ps. pyocyanea and remained untreated (Nos 9 and 10) a heavy infection resulted, and the same occurred in two infected eyes to which empty calcium alginate caps were applied.

\section{Ocular Effects of Use of Caps}

Since the calcium alginate caps were used with a view to their possible clinical application, it was necessary to discover whether the eye tolerated them well or not. (Experiments 13 and 14). Empty calcium alginate caps were applied to two healthy rabbit eyes and the lids were sutured as in the other experiments. When, after $24 \mathrm{hrs}$, the caps were removed, some discharge and a slight corneal haze were noticed but these cleared up in a few days without leaving any scarring on the cornea. This transitory corneal haze was also noted in the treated eyes which healed. It seems that a very intensive pharmacological effect can be obtained with this form of local application, but that further investigations are needed to find a more suitable substance which the eye will tolerate without irritation.

\section{Summary}

A single dose of chloramphenicol powder administered in calcium alginate caps gave protection against experimental Ps. pyocyanea infection of rabbit 
corneae in two eyes out of six. This result compares unfavourably with the effect of streptomycin (Klein and Millwood, 1953), for a single dose of streptomycin powder in calcium alginate caps or glycerin-gelatine disks gave almost certain protection. This difference may be explained by the fact that streptomycin is bactericidal whereas chloramphenicol is bacteriostatic. The application of non-medicated calcium alginate caps caused a transitory corneal haze in healthy rabbit eyes.

Our thanks are due to Dr. W. W. Walther for permission and facilities to carry out the experiments in the Area Laboratory, Whipps Cross Hospital, London, to Messrs. G. Nissel for the supply of metal moulds, and to Messrs. Albright and Wilson, Oldbury, Birmingham, for the supply of the alginate.

\section{REFERENCES}

Azzolini, U., and FaLdI, S. (1950). G. ital. Oftal., 3, 211. Abstracted in Excerpta med., Amst., Sect. XII (1950), 4, 653 (No. 2129).

KLEIN, M., and MILLWOod, E. G. (1953). British Journal of Ophthalmology, 37 (in the press).

LANGHAM, M. (1951). Ibid., 35, 614.

LEOPOLD, I. H. (1951). Arch. Ophthal., Chicago, 45, 44.

- Nichols, A. C., and Vogel, A. W. (1950). Ibid., 44, 22.

SorsBy, A. (1951). Proc. roy. Soc. Med., 44, 737. 